\title{
Da falência à liderança: a trajetória do Grupo Votorantim no setor têxtil paulista (1918-1939)
}

\author{
Gustavo Pereira da Silva ${ }^{1}$ \\ Armando Dalla Costa ${ }^{2}$
}

\section{Área ANPEC: 03 - História Econômica}

\begin{abstract}
Resumo: A compreensão dos grupos econômicos brasileiros apresenta uma lacuna, sobretudo, no entendimento de como esses grupos se formaram na primeira metade do século XX. O Grupo Votorantim, oitavo maior grupo brasileiro em 2007, surgiu no final do século XIX, mas ganhou sua definição empresarial em 1918, quando foi adquirido pelo empresário Antonio Pereira Ignácio. Nas décadas de 1920 e 1930, o principal empreendimento da Sociedade Anônima Fábrica Votorantim (SAFV) era a fábrica têxtil, localizada em Sorocaba (SP), próxima dos outros empreendimentos do grupo (ferrovia, cal e cimento, venda de terrenos, usina hidrelétrica). Analisando fontes primárias da SAFV (balanços patrimoniais, demonstrações de lucros e perdas, relatórios de diretoria) e os levantamentos sobre a indústria paulista, evidenciamos sua evolução ao posto de principal empresa têxtil paulista na década de 1930, evolução apoiada em três fatores: sua constituição como um grupo econômico, sua administração familiar e suas ligações com o setor financeiro paulista.
\end{abstract}

Palavras-Chaves: Votorantim, grupo econômico, têxtil.

Abstract: Understanding the Brazilian economic groups presents a gap, especially in understanding how these groups were formed in the first half of the twentieth century. The Votorantim Group, eighth largest Brazilian group in 2007, emerged in the late nineteenth century, but gained its business definition in 1918, when it was acquired by businessman Antonio Pereira Ignacio. In the 1920 and 1930s, the major undertaking of Sociedade Anônima Fábrica Votorantim (SAFV) was a textile factory, located in Sorocaba (SP), close to the other group undertakings (railway, lime and cement, sale of land, hydroelectric power plant). Analyzing primary sources of SAFV (balance sheets, profit and loss statements, management reports) and surveys on the São Paulo industry, we noted its evolution to become the biggest textile company in the state of São Paulo in the 1930s, progress based on three factors: its constitution as a business group, its family management and its links to the São Paulo's financial sector.

Keywords: Votorantim, business group, textile.

CLASSIFICAÇÃO JEL: L67, N66, N86.

\section{1 - Introdução}

Na década de 1920, a indústria paulista era a de maior relevância nacional, pois, em 1919, 31,5\% do valor produção industrial brasileira vinha de São Paulo, secundado pelo estado do Rio de Janeiro com $28,2 \%$ do total. Dos variados setores industriais, o têxtil se notabilizava como o mais expressivo, tanto no nível estadual quanto federal: em 1919, 29\% do produto industrial brasileiro teve origem no setor têxtil, cifra análoga à participação dos têxteis na indústria paulista, sendo que São Paulo abrigava 30\% das fábricas têxteis brasileiras e $27 \%$ do capital investido no setor, além de $34 \%$ dos operários nacionais (Negri, 1996, p. 37; Baer, 2002, p. 60; Loureiro, 2006, p. 32) ${ }^{3}$.

Uma estrutura de oligopólio competitivo grassava no setor têxtil paulista, pois $70 \%$ do capital investido vinham de apenas $12,5 \%$ das fábricas que, além disso, empregavam $70 \%$ dos trabalhadores têxteis. A explicação para tamanha concentração estava nos condicionantes à montagem das fábricas têxteis, sobretudo as maiores: vários fusos e teares implicavam na aquisição de muitas máquinas e, principalmente, investimentos na geração de energia para alimentar a produção. Dos ramos que compunham o setor têxtil no estado de São Paulo - fiação e tecelagem de algodão, fiação e tecelagem de

\footnotetext{
${ }^{1}$ Professor Adjunto no Departamento de Economia da Universidade Federal do Paraná. Email: gustavopereira@ufpr.br

2 Professor Associado no Departamento de Economia e no Programa de Pós-Graduação em Desenvolvimento Econômico da Universidade Federal do Paraná. Email: ajdcosta@uol.com.br

${ }^{3} \mathrm{O}$ crescimento industrial visto na economia brasileira durante a Primeira República - predomínio da formação de uma indústria de bens de consumo assalariado - teve como indutor a rentabilidade e oportunidades geradas pelo café. Mão-de-obra, mercado consumidor, cambiais para a importação de máquinas e matérias-primas, o desejo dos fazendeiros em rebaixar os custos de manutenção da mão-de-obra através da produção interna de alguns gêneros (como roupas), estes fatores foram suscitados pelas exportações cafeeiras e encontraram ressonância de um setor industrial cuja tecnologia já estava consolidada nos países desenvolvidos, ao final do século XIX, possibilitando plantas industriais de menor escala - comparadas ao setor de bens de capital, como a siderurgia - e com aportes de capitais mais compatíveis à realidade dos empresários brasileiros, que puderam importar máquinas e formar um setor têxtil nacional (Mello, 2009; Cano, 1981; Aureliano, 1999; Silva, 1995).
} 
juta, fábricas de seda natural e artificial (rayon), as malharias e as fábricas de la -o ramo algodoeiro era o principal, pois enquanto suas fábricas representavam $31,5 \%$ do setor, ao mesmo tempo, nelas estavam $64,5 \%$ do capita, somavam $60,6 \%$ dos trabalhadores têxteis e $74,6 \%$ da força motriz, elementos que reunidos permitiam ao ramo algodoeiro alcançar 43,4\% da produção do setor (Aureliano, 1999, p. 40; Loureiro, 2006, p. 33) ${ }^{4}$.

Uma das maiores fábricas têxteis paulistas nas décadas iniciais do século XX era a Sociedade Anônima Fábrica Votorantim, localizada na cidade de Sorocaba. A empresa foi criada em 1891 pelo Banco União de São Paulo - a maior casa bancária paulista do período - e, com a falência do banco em 1917, arrematada pelos empresários Antonio Pereira Ignácio e Francisco Scarpa em janeiro de 1918. Nos 20 anos subsequentes, a Fábrica Votorantim converteu-se de parte da massa falida do Banco União para o posto de principal firma têxtil do Estado de São Paulo - segundo o montante do capital investido - no ano de 1931, fato que se repetiria no período 1935-1937.

Em que pese relevantes trabalhos terem se debruçado sobre a indústria têxtil paulista, tais estudos o fizeram de uma maneira setorial, na maioria das vezes, sem tomar como objeto de análise uma empresa específica, suas políticas de gestão e seus resultados contábeis no período do Entreguerras ${ }^{5}$. No caso da Fábrica Votorantim, os trabalhos ${ }^{6}$ arrolados demonstram uma preocupação maior com o processo de internacionalização do Grupo Votorantim, que se adensou na década de 1980, momento em que a Votorantim já havia se consolidado na setor industrial de base, dessa forma, permanecendo lacunas sobre o evolver dos negócios têxteis, a atividade central do grupo até o final dos anos 1930. Ademais, a lacuna apontada é de extensão mais ampla se considerada a escassez de informações sobre a origem dos maiores grupos econômicos do Brasil, lista que, para o ano de 2007, colocava o Grupo Votorantim como o principal conglomerado industrial de origem privada/familiar na economia brasileira, ao lado de empresas estatais e bancos que comungam o fato de terem surgido antes da década de 1960 (Aldrighi e Postali, 2010, p. $355-356)^{7}$.

Diante disso, o artigo tem como objeto o evolver da Sociedade Anônima Fábrica Votorantim doravante SAFV (grupo de empresas) ou Fábrica Votorantim (referindo-se somente à firma têxtil) - razão social da fábrica têxtil e de investimentos paralelos que compunham o grupo econômico liderado por Antonio Pereira Ignacio e José Ermírio de Moraes nas décadas de 1920 e 1930. O foco recai sobre a atuação da Fábrica Votorantim no setor têxtil paulista entre 1919-1939, buscando compreender como ocorreu a reestruturação da empresa e do grupo após a falência do Banco União de São Paulo em 1918 seu controlador até então - e, sobretudo, como se deu a guinada empresarial da Fábrica Votorantim, que a transformou na maior firma têxtil de São Paulo na década de 1930. Para tanto, utilizamos as

\footnotetext{
${ }^{4}$ A preeminência do algodão no setor têxtil, que organizou as primeiras manufaturas na década de 1840, deve-se aos seguintes fatores: oferta de matéria-prima em algumas regiões do Brasil, como o Norte-Nordeste e no interior de São Paulo; a expansão das economias regionais a demandar, por exemplo, vestuário, sacaria para armazenagem dos produtos; oferta de mão-de-obra barata; além de alguma proteção à indústria nacional, que eventualmente se valia da elevação dos impostos de importação (como a Tarifa Alves Branco em 1844) e/ou da desvalorização cambial (Suzigan, 2000, p. 130).

5 (Stein, 1979; Loureiro, 2006; Baer, 1975; Carone, 2001; Cano, 1981; Negri, 1996; Suzigan, 2000; Dean, 1971; Versiani e Versiani, 1977; Ribeiro, 1988). Um estudo específico sobre uma das mais importantes firmas têxteis fluminenses é de Weid, Elisabeth von der. O fio da meada: estratégia de expansão de uma indústria têxtil: Companhia América Fabril, 1878-1930. Rio de Janeiro: FCRB: CNI, 1986.

${ }^{6}$ (Santos, 2008). Devemos registrar que alguns trabalhos se reportaram às figuras-chaves para o desenvolvimento do Grupo Votorantim, caso de Scantimburgo, J. José Ermírio de Moraes: o homem, a obra. São Paulo: Companhia Editora Nacional, 1975; e Pastore, J. Antonio Ermírio de Moraes: memórias de um diário confidencial. São Paulo: Planeta, 2013. Nesta mesma linha hagiográfica situa-se a obra de Caldeira, J. Votorantim 90 anos: uma história de trabalho e superação. São Paulo, SP: Mameluco, 2007.

${ }^{7}$ Os dez maiores grupos econômicos do Brasil em 2007 eram, em ordem crescente de receita bruta (em parênteses o ano de fundação): Fiat (1899), Gerdau (1909), Votorantim (1892), Ambev (1999), Telefônica (1924), Banco do Brasil (1808), Itaú (1945), Vale (1942), Bradesco (1943) e Petrobrás (1953) (Aldrighi e Postali, 2010, p. 355-356). Existem trabalhos que traçam um panorama histórico dos grupos econômicos brasileiros, mas que não empreenderam análises mais específicas, sobretudo ao período da primeira metade do século XX, caso de Bonelli (1998) e Gonçalves (1999).
} 
demonstrações contábeis da Sociedade Anônima Fábrica Votorantim (Balanços Gerais e Demonstrações de Lucros e Perdas), os Relatórios da Diretoria da SAFV e os levantamentos sobre a indústria paulista no Entreguerras (Estatística Industrial de São Paulo e Boletim da Diretoria de Indústria e Comércio do Estado de São Paulo). De antemão, vemos três fatores que fundamentaram a evolução da Fábrica Votorantim no setor têxtil paulista: sua constituição como um grupo econômico, as ligações com o setor financeiro paulista e a administração familiar do grupo. A Votorantim tinha como atividade central a fábrica têxtil em Sorocaba, mas tratava-se de um grupo econômico composto por outros empreendimentos (ferrovia, cimento e cal, usinas de beneficiamento de algodão, usina hidrelétrica, produção de adubos, óleos vegetais, sabão) que reduziam os custos produtivos e de transação, por exemplo, no transporte de suas mercadorias. De outra parte, a SAFV tinha ligações diretivas com o maior banco paulista dos anos 1920, o Banco do Comércio e Indústria de São Paulo - que fazia parte do conselho fiscal do grupo -, nexo que permitia à firma valer-se dos capitais de terceiros como principal fonte de financiamento às suas amplas atividades industriais, de acordo com a análise dos balanços da empresa. A estes dois fatores somamos a administração familiar dos negócios, marcada pelo controle acionário do grupo por Antonio Pereira Ignácio e a gerência de José Ermírio de Moraes a partir de 1925, que possibilitou uma política de não distribuição de dividendos que reforçava as reservas da empresa, capitais que seriam de grande valia quando da Crise de 1929, momento em o Grupo Votorantim ampliou os investimentos em máquinas têxteis e financiou produtores de algodão para garantir obtenção de matéria-prima. Estas três bases foram de suma importância à expansão da Fábrica Votorantim frente às congêneres, que se traduziria em uma saída mais célere da Crise de 1929 e chegando à liderança no setor têxtil paulista, alcançada no começo dos anos 1930 e apresentada em outros momentos daquela década.

\section{2 - Sociedade Anônima Fábrica Votorantim: as origens de um grupo econômico brasileiro}

O enquadramento teórico das grandes empresas de economias emergentes no começo do século XX - América Latina e Ásia - buscou no conceito de grupos econômicos uma melhor compreensão deste objeto $^{8}$. Em que pese os grupos econômicos não serem conceituados de maneira unívoca, as definições mais usuais os descrevem como grupos de empresas que podem ser juridicamente independentes, mas que atuam de maneira conjunta através de laços formais - como o patrimônio - e/ou informais, como família ${ }^{9}$. Estes grupos caracterizam-se pela atuação diversificada que, no caso dos grupos econômicos brasileiros, deve se dar pelo menos em três setores industriais (Aldrighi e Postali, 2010, p. 371).

A união com outras empresas independentes para formar grupos econômicos tendia a minimizar os obstáculos à atuação destas companhias em mercados nascentes nos países em desenvolvimento, diminuindo os custos de transação. Questões fundamentais no cotidiano empresarial como o acesso ao crédito, às fontes de matérias-primas, ao transporte das mercadorias finais, a instabilidade dos marcos regulatórios, a diversidade dos produtos e as próprias flutuações econômicas conjunturais tinham na formação de grupos econômicos uma resposta às condicionalidades de mercados imperfeitos (Leff, 1978, p. 666-675; Barbero, 2011, p. 5-6; Kim, Kandemir e Cavusgil, 2004, p. 3).

A comandar os grupos econômicos, como no caso brasileiro, comumente vemos famílias - Ermírio de Moraes, Gerdau, Setúbal e Vilela dentre outras - que detêm posições de controle nestas alianças de empresas $^{10}$. Articuladas em uma cadeia de gestão piramidal, ou eventualmente como holdings, estas

\footnotetext{
${ }^{8}$ Os grupos econômicos receberam diferentes nomenclaturas nos países emergentes: na Coréia do Sul são os chaebols; na Índia os business houses; na Turquia as holding companies; e, na América Latina se consagrou, inclusive no Brasil, o termo grupos econômicos (Kim, Kandemir e Cavusgil, 2004, p. 14).

${ }^{9}$ Esta caracterização dos grupos econômicos enquanto conjunto de empresas independentes que atuam de maneira congregada pode ser encontrada em Granovetter (2005, p. 429), Khanna e Yafhe, (2007, p. 331), Colpan e Hikino (2010, p. 17) e Gonçalves (1991, p. 181).

${ }^{10}$ Em 2007, dos 50 maiores grupos econômicos atuando no mercado brasileiro, 15 eram comandados por famílias nacionais, enquanto 21 eram controlados por firmas estrangeiras - que podiam ser firmas familiares -, 8 grupos eram dirigidos por firmas
} 
famílias comandam as empresas através do controle acionário do grupo - pressupondo a paridade açãovoto -, maioria acionária que pode ser resultado de um único grande acionista - o fundador ou comprador da empresa - ou de alguns familiares com posse relevante de papéis do grupo, sendo que alguns destes indivíduos traduzem o controle da família através da participação direta em posições de controle estratégico, como a presidência ou gerência (Granovetter, 2005, p. 433; Colpan e Hikino, 2010, p. 16; Fernandez-Perez, 2010, p. 148; Fernandez-Perez e Casanova, 2012, p. 281).

Dentre os dez maiores grupos econômicos brasileiros em 2007 constava o Grupo Votorantim, notadamente o maior dos grupos privados a atuar na indústria e cujas origens remontam ao final do século XIX. Em julho de 1891, o Banco União de São Paulo adquiriu terras na localidade paulista de Sorocaba ${ }^{11}$. A região era o principal centro algodoeiro de São Paulo e nas terras compradas situava-se uma cachoeira de nome Votorantim (no Rio Sorocaba) ${ }^{12}$. Esta queda d'água possibilitou ao banco solucionar uma questão-chave ao funcionamento de sua Fábrica de Chitas Votorantim ${ }^{13}$, unidade fabril têxtil formada em 1891 e que passou a funcionar no ano seguinte, quando a pequena usina hidrelétrica construída pelo banco também foi concluída e passou a alimentar os teares e fusos da fábrica ${ }^{14}$. Estes dois empreendimentos foram complementados pelo banco que, a fim de viabilizar a chegada de matéria-prima e o escoamento da produção, engendrou uma ferrovia - a Estrada de Ferro Votorantim - que, apesar de sua pequena extensão de somente 8 quilômetros, servia para interligar o nascente distrito de Votorantim à cidade de Sorocaba, onde se encontravam com os trilhos da Estrada de Ferro Sorocabana a unir o mercado local ao estadual (EFEV, p.1) ${ }^{15}$.

Esta conjuntura favorável aos investimentos industriais foi revertida a partir de 1914, com as dificuldades econômicas impostas pela I Guerra Mundial, sobretudo com a diminuição dos fluxos comerciais do exterior, implicando em dificuldades na obtenção de matérias-primas - caso dos tecidos ingleses posteriormente finalizados no Brasil - e equipamentos. Ademais, com a queda nos preços do café, houve uma fuga de cambiais do sistema bancário paulista - que levou ao fechamento da Caixa de Conversão - gerando a falência de algumas instituições financeiras (Saes, 1986, p. 144; Villela e Suzigan, 1973, p. 128). Uma delas foi o Banco União de São Paulo que, em 9 de janeiro de 1918, leiloou seus ativos, dentre eles a Fábrica Têxtil Votorantim (fiação, tecelagem e estamparia), que foi arrematada pelos empresário português Antonio Pereira Ignácio e o italiano Francisco Scarpa - que até então eram fornecedores da Fábrica Votorantim ${ }^{16}$ - além de outros acionistas menores, pelo valor de 5 mil contos de réis, montante que se dizia ser oito vezes menor que o valor dos ativos adquiridos na região de Sorocaba, pois além da unidade têxtil, com seus estoques e maquinários, eles se tornaram proprietários da Estrada

privadas e/ou fundos de pensão nacionais, 5 grupos eram estatais e 1 grupo era chefiado de maneira conjunta por uma família brasileira e uma empresa estrangeira (Aldrighi e Postali, 2010, p. 372).

${ }^{11}$ O Banco União de São Paulo, que tinha como presidente o senador Antonio de Lacerda Franco e em sua diretoria outros representantes do grande capital cafeeiro, foi criado em janeiro de 1890 e, em 1892, era o maior banco paulista de acordo com o volume de seus ativos (Hanley, 2005, p. 155).

${ }^{12} \mathrm{Na}$ primeira década do século XX, a região de Sorocaba era responsável por $80 \%$ da produção de algodão paulista (Carone, 2001, p. 93).

${ }^{13}$ Chita era um tecido de algodão importado, principalmente da Inglaterra, e posteriormente estampado no Brasil.

14 Como a maior parte da produção energética do estado de São Paulo se destinava ao consumo doméstico, os empreendimentos industriais tinham na viabilização energética um grande desafio ao funcionamento de suas instalações. Disto vinha a preferência por situar as plantas industriais próximas aos rios e suas quedas d'água, que permitiam a construção de pequenas usinas hidrelétricas que alimentariam as fábricas (Carone, 2001, p. 81-86).

${ }^{15}$ Inicialmente, a Estrada de Ferro Votorantim contava com 5 locomotivas, 30 vagões de carga, 8 carros de passageiros e 1 carro especial para autoridades, além de 1 carro fúnebre (EFEV, p.1).

${ }^{16}$ Antonio Pereira Ignácio fornecia algodão descaroçado através de sua empresa, a Fábrica de Óleos Santa Helena, situada em Sorocaba (SP). O italiano Francisco Scarpa, através da F. Scarpa \& Filho, casa importadora de gêneros diversos, tinha um armazém dentro das instalações da Fábrica Votorantim para atender os funcionários da firma têxtil (Lloyd et al, 1913, p. 651 apud http://www.novomilenio.inf.br/santos/h0300g39i.htm.) 
de Ferro Votorantim e de jazidas de cal (Caieiras de Itupararanga) que também eram atendidas pela ferrovia particular da Votorantim ${ }^{17}$ (SAFV, 1918-1919; Marcovitch, 2009, p. 234) ${ }^{18}$.

\section{Tabela 1: Empresas componentes da Sociedade Anônima Fábrica Votorantim, 1918-1929}

\begin{tabular}{|c|c|c|c|}
\hline Nome da empresa & Ano de criação & Cidade & Produção/Finalidade \\
\hline Fábrica Votorantim & 1892 & Votorantim (SP) & tecidos de algodão \\
\hline Fábrica Rodovalho & 1892 & São Roque (SP) & cimento \\
\hline Caieiras de Itupararanga & Desconhecido & Sorocaba (SP) & cal \\
\hline $\begin{array}{c}\text { Estrada de Ferro Elétrica } \\
\text { Votorantim }\end{array}$ & 1893 & Sorocaba (SP) & transporte \\
\hline
\end{tabular}

Fonte: SÃO PAULO. Diário Oficial do Estado de São Paulo, 30/06/1922, p. 1922; 15/02/1923, p. 1923; 14/02/1925, p. 1233; 12/02/1926, p. 1243; 15/02/1928, p. 1471; 23/02/1930, p. 1995.

Em virtude de desavenças com o sócio, Francisco Scarpa vendeu sua participação na Fábrica Votorantim para Pereira Ignácio por dois mil contos de réis, tendo recebido do português também a Fábrica de Óleos Santa Helena. Pereira Ignácio, que já era um dos mais prósperos empresários paulistas, aceitou a oferta e fez da Votorantim seu principal investimento, concentrando esforços no setor têxtil paulista através do controle acionário da Sociedade Anônima Fábrica Votorantim (Marcovitch, 2009, p. $236)^{19}$.

Este controle é evidenciado pelo quadro de acionistas da SAFV em 15 de fevereiro de 1924, ao demonstrar que Antonio Pereira Ignácio (presidente da SAFV) tinha 99,44\% das ações do grupo em 1924 - 12.500 ações em seu nome e mais 12.360 ações em nome da Pereira Ignácio \& Cia. que era a reunião de seus diversos empreendimentos individuais. Ademais, seus filhos Paulo e João Pereira Ignácio possuíam cada um 20 ações (0,08\% dos papéis), o que punha em mãos da família um total de 99,60\% das 25.000 ações em que se dividia o capital do grupo ${ }^{20}$.

Na década de 1920, a SAFV tinha uma gama de recursos produtivos em que se destacava a fábrica têxtil, empreendimento que centralizava as atenções do grupo e seria responsável por $80 \%$ das receitas da SAFV no período, conforme a tabela 2 abaixo.

\footnotetext{
${ }^{17}$ A Fazenda do Itupararanga era propriedade do Banco União de São Paulo no começo do século XX. Situada próxima à Sorocaba, nela existiam quedas d'água do Rio Sorocaba que possibilitaram a formação de uma usina hidrelétrica que fornece energia para empresas do Grupo Votorantim até hoje. Além disso, a barragem atualmente fornece água aos municípios de Ibiúna, Sorocaba, Votorantim, São Roque e outros da região. Nas terras da fazenda eram exploradas jazidas de cal, as caieiras de Itupararanga.

${ }^{18} \mathrm{Em}$ 1918, na Fábrica Votorantim havia 1.300 teares e 66.000 fusos, o que fazia dela a segunda maior fábrica têxtil paulista em capacidade produtiva, atrás somente do Cotonifício Crespi (cidade de São Paulo). A fábrica sorocabana produzia algodões, chitas, morins, brins, cassas, lenços, toalhas, e flaneletas, empregando nestas atividades 1.800 operários. A fábrica tinha uma área construída de 100.000 metros quadrados e os terrenos anexos somavam 1,88 milhão de metros quadrados, ademais, havia 1.500 alqueires de terras de cultura, campos e matas. Em relação à Estrada de Ferro Votorantim, havia quatro locomotivas de quatorze toneladas, sete vagões de passageiros e vagões de carga (Marcovitch, 2009, p. 234-235).

19 Antonio Pereira Ignácio, português que chegou ao Brasil em 1884 com 10 anos de idade para viver com sua família na cidade paulista de Sorocaba, iniciou a trajetória econômica no Rio de Janeiro, trabalhando na casa importadora de tecidos do português João Reinaldo Faria. Com o cabedal acumulado, voltou para a região sorocabana no final do XIX e investiu no setor algodoeiro, chegando a ser proprietário de 14 empresas descaroçadoras de algodão espalhadas pela cidade de Boituva, Porto Feliz, Tatuí e Conchas, localidades situadas entre Piracicaba e Sorocaba. Utilizando a mesma matéria-prima, ele montou em 1905, na cidade de Sorocaba, a Fábrica de Óleos Santa Helena, que descaroçava o algodão a ser vendido às empresas têxteis e também produzia o óleo. No setor têxtil, ele ainda adquirira três tecelagens: Fábrica Paulistana, Fábrica Luzitânia e Fábrica Lucinda. Ademais, Pereira Ignácio diversificara seus negócios comprando a Companhia Telefônica Sul Paulista e a Fábrica de Cimento Rodovalho (Marcovitch, 2009, p. 235; Caldeira, 2007, p. 18).

${ }^{20}$ Os demais acionistas da S. A. Fábrica Votorantim em fevereiro de 1924 eram: Zeferino de Freitas Guimarães, Antonio Oliveira Penteado, A. de Carvalho e Silva, Jorge Nielsen, Mario Goulart de Faria, sendo que cada um deles possuía 20 ações (SAFV, 1923, p. 13).
} 
Tabela 2: Receitas da S. A. Fábrica Votorantim, 1921-1927 - valores em contos de réis correntes

\begin{tabular}{|l|c|c|c|c|c|}
\hline & $\mathbf{1 9 2 1}$ & $\mathbf{1 9 2 2}$ & $\mathbf{1 9 2 4}$ & $\mathbf{1 9 2 5}$ & $\mathbf{1 9 2 7}$ \\
\hline Votorantim (fábrica têxtil) & 5.337 & 3.026 & 8.479 & 6.900 & 4.099 \\
\hline Itupararanga (cal) & 438 & 227 & 416 & 456 & 1.031 \\
\hline Rodovalho (cimento) & 83 & 44 & 46 & 32 & 47 \\
\hline Diversos & 419 & 470 & 939 & 190 & 0 \\
\hline Estrada de Ferro Elétrica & & & 71 & 114 & 825 \\
\hline Seção de Terrenos & & & & 765 & 799 \\
\hline Renda de imóveis & 41 & 30 & 51 & 17 & \\
\hline Total & 6.319 & 3.800 & 10.004 & 8.478 & 6.801 \\
\hline
\end{tabular}

Fonte: SÃO PAULO. Diário Oficial do Estado de São Paulo, 30/06/1922, p. 1922; 15/02/1923, p. 1923; 14/02/1925, p. $1233 ; 12 / 02 / 1926$, p. $1243 ; 15 / 02 / 1928$, p. 1471.

Nota: Os dados foram extraídos das Declarações de Lucros e Perdas publicadas no Diário Oficial do Estado de São Paulo. A diferença entre a soma dos itens da Receita e o total se deve ao arredondamento dos dados.

Concentrando suas atividades no principal ramo têxtil, a Fábrica Votorantim ganharia postos, entre 1919-1937, que a conduziriam de uma posição de fragilidade financeira quando de sua venda a Pereira Ignácio à liderança deste que era o principal setor da indústria paulista e nacional.

\section{3 - A evolução da S. A. Fábrica Votorantim no setor têxtil paulista (1919-1939)}

Após enfrentar dificuldades com a reposição de maquinário e fornecimento de matérias-primas durante a I Guerra Mundial (1914-1918), a indústria têxtil nacional iniciaria uma nova fase de investimentos na década de 1920. Favorecida, mesmo que indiretamente, por uma taxa de câmbio mais valorizada, principalmente entre 1924-1926, além de contar com a expansão dos meios de pagamentos exceto pelo ano de 1926 - a importação de maquinaria têxtil para as firmas algodoeiras sextuplicaria entre 1921-1926 (Suzigan, 2000, p. 159-160; Cano, 2012, p. 903; Negri, 1996, p. 37).

A ampliação da capacidade produtiva na década de 1920 ocorreu de forma análoga nas firmas têxteis paulistas, sendo o Estado de São Paulo responsável pela produção de aproximadamente metade dos tecidos de algodão nacionais no decênio ${ }^{21}$. Uma das principais empresas têxteis paulistas era a Fábrica Votorantim que, em 1920, egressa de um processo quase falimentar marcado por atrasos salariais e quebra no fornecimento de matéria-prima, encontrava-se na quinta posição entre as companhias produtoras de tecidos de algodão no Estado de São Paulo, de acordo com o capital investido, ficando atrás de firmas da capital paulista ${ }^{22}$.

No caso da Fábrica Votorantim, as instalações sorocabanas, que sofriam pela obsolescência dos equipamentos, receberam máquinas importadas e aprimoramentos nas já existentes que permitiram à SAFV, entre 1918-1923, dobrar sua produção têxtil - de quase 13 milhões de metros de tecidos para pouco mais de 24 milhões de metros ${ }^{23}$. Além dos investimentos na fábrica têxtil, ocorreu a eletrificação e

\footnotetext{
${ }^{21}$ Em 1920, as firmas do setor têxtil algodoeiro paulista tinham um total de 16.100 teares e 524.000 fusos que produziram 186.500.000 metros de tecidos. Já, em 1928, elas possuíam 22.800 teares e 730.800 fusos que produziram 191.100 .000 metros de tecidos. Em que pese o aumento da produção não ter sido tão elevado comparado ao da capacidade produtiva, o aumento da produção nas firmas têxteis paulistas entre 1920-1928 contrasta com a queda na produção de tecidos de algodão vista no restante do país, pois em 1920, excluindo São Paulo, as firmas nacionais produziram 400.700.000 de metros de tecidos, enquanto em 1928, esse número caiu para 390.900.000 de metros (Cano, 1981, p. 293).

22 As maiores fábricas de tecidos de algodão do Estado de São Paulo, segundo o capital investido, eram: Cia. Nacional de Tecidos de Juta (10 mil contos de réis); Cotonifício Rodolfo Crespi (7.729 contos de réis); Fábrica de Tecidos Labor (7.600 contos de réis); Fiação, Tecelagem e Estamparia Jafet (6.419 contos de réis); e Sociedade Anônima Fábrica Votorantim (6.000 contos de réis) (DEIC/SACOP/SP. Boletim da Diretoria de Indústria e Comércio, 1922, p. 60-63).

${ }^{23}$ No Relatório da Diretoria da SAFV relativo ao ano de 1923 consta que "Adquirimos o estabelecimento em julho de 1917, sendo que, nesse ano, foi quase nula a sua eficiência de trabalhos, em virtude da reforma geral que a fábrica necessitava".
} 
o alargamento de bitola dos trilhos da Estrada de Ferro Votorantim, que atendia, além da fábrica têxtil, as Caieiras de Itupararanga (Sorocaba-SP) e a Fábrica de Cimento Rodovalho (São Roque-SP) ${ }^{24}$.

O ramo algodoeiro paulista, entre os anos 1926-1928, apresentou uma queda de mais de $20 \%$ de sua produção, ao passo que aumentava a importação de tecidos pelo Porto de Santos. A Fábrica Votorantim, por sua vez, teve um crescimento de $26,03 \%$ em seu ativo e de $54,45 \%$ no patrimônio líquido - conforme tabela 3 abaixo - expansão marcada pelo aumento do capital social do grupo, que passou de 5.000 contos de réis para 20.000 mil contos em 1927. Ademais, enquanto muitas firmas algodoeiras amargavam queda na produção, outras, como a Fábrica Votorantim, demonstravam melhores indicadores calcados na produção de tecidos de maior qualidade - a fábrica sorocabana produzia tecidos tintos, alvejados e estampados (Loureiro, 2006, p. 50; Cano, 1981, p. 184; Suzigan, 1971, p. 93$)^{25}$.

Tabela 3: Variação real das contas do balanço patrimonial da Sociedade Anônima Fábrica Votorantim, 1924-1933 - variação real (ano base $=1924)$

\begin{tabular}{|c|c|c|c|c|c|c|c|}
\hline ANO & $\mathbf{1 9 2 5}$ & $\mathbf{1 9 2 7}$ & $\mathbf{1 9 2 9}$ & $\mathbf{1 9 3 0}$ & $\mathbf{1 9 3 1}$ & $\mathbf{1 9 3 2}$ & $\mathbf{1 9 3 3}$ \\
\hline Ativo (\%) & $-10,41$ & 26,03 & 2,54 & 15,19 & 33,38 & 32,08 & 35,05 \\
\hline Passivo (\%) & $-12,26$ & 9,86 & 8,84 & 21,49 & 36,98 & 32,93 & 32,16 \\
\hline Patrimônio Líquido (\%) & $-7,17$ & 54,45 & $-8,53$ & 4,11 & 27,04 & 30,60 & 40,13 \\
\hline
\end{tabular}

Fonte: SÃO PAULO. Diário Oficial do Estado de São Paulo, 14/02/1925, p. 1233; 12/02/1926, p. 1243; 16/02/1928, p. $1953 ; 22 / 03 / 1931$, p. $2327 ; 25 / 02 / 1932$, p. $15 ; 25 / 02 / 1933$, p. $1525 / 02 / 1934$, p. 32.

Nota: para obter a variação real das contas do balanço foi utilizado o Deflator Implícito do PIB elaborado pelo ipeadata (http://www.ipeadata.gov.br/) com base no trabalho de Haddad, Claudio Luiz da Silva. Crescimento do produto real no Brasil, 1900-1947. Rio de Janeiro: Fundação Getúlio Vargas, 1978.

A Crise de 1929 agudizou ainda mais o cenário adverso vivido pelo ramo algodoeiro, sobretudo, devido à queda nos preços do café e seus efeitos declinantes na demanda por artigos têxteis. Refletindo a retração geral da indústria paulista entre 1929-1930, o setor têxtil teve queda acentuada no número de operários, na produção e nos valores que ele gerou, crise marcada pela paralisação de importantes firmas algodoeiras, caso do Cotonifício Scarpa S. A. que, em 1930, era a maior empresa do setor têxtil ${ }^{26}$. Conforme a tabela 3 anterior, houve um declínio no ativo da SAFV nos anos de 1929 e 1930, comparados ao ano de 1927, fato que deu-se em virtude da corrosão dos valores do estoque de mercadorias e matériasprimas e, também, dos ativos permanentes do grupo (fábrica têxtil, terrenos, cimento, ferrovia, fábrica de

Ademais, "No tocante aos melhoramentos aplicados nos maquinismos existentes, verificamos, com a aplicação prática na fiação, que o processo de uniformização de uma só canilha produz um aumento de $26 \%$, com diminuição de $20 \%$ da mão-deobra" (SAFV, 1923, p. 3).

${ }^{24}$ A eletrificação e o alargamento da bitola proporcionaram um crescimento no fluxo de passageiros e no transporte de mercadorias pela Estrada de Ferro Elétrica Votorantim, visto que, em 1918, foram comercializados 62.087 bilhetes de passageiros e transportadas 69.054 toneladas de mercadorias. Ao passo que, em 1923, foram vendidos 174.122 bilhetes de passageiros e transportados 948.829 toneladas de mercadorias (SAFV, 1923, p. 5).

${ }_{25}$ As agruras do setor têxtil paulista entre 1926-1928 explicavam-se pela maior inserção dos tecidos estrangeiros no mercado nacional - sobretudo os ingleses -, sendo que estas mercadorias tinham uma grande demanda em virtude de sua qualidade mais elevada e de preços competitivos, o último fator em virtude da baixa proteção alfandegária em contexto de crescimento dos preços internos. Ademais, a capacidade produtiva nacional foi amplamente acrescida na década de 1920, o que agravava o descompasso entre uma oferta crescente e uma demanda que era eventualmente desviada aos produtos importados (Luz, 1975, p. 179; Suzigan, 1971, p. 94; Stein, 1979, p. 130-131).

${ }_{26}$ Em 1929, o Estado de São Paulo tinha 22 empresas têxteis com atividades paralisadas em decorrência da crise, sendo 15 do ramo algodoeiro. O número de operários no setor têxtil em 1930 era $28 \%$ menor do que em 1928, a produção de tecidos caiu $30 \%$ no mesmo período e o valor da produção era quase $30 \%$ menor do que em 1928 . No ramo algodoeiro, o operariado declinou 44,2\% em relação ao ano de 1928, queda que se deu de maneira análoga no valor da produção (22,1\%) e no capital investido (10\%) (Loureiro, 2006, p. 65; Suzigan, 1971, p. 96). 
cal) - conforme os balanços da SAFV no anexo 1 . Queda ainda maior se deu com o patrimônio líquido em 1929, devido à utilização das reservas como forma de financiamento em meio à crise ${ }^{27}$.

No interregno entre 1929-1932, marcado pela crise aguda no setor têxtil, o ramo algodoeiro apresentou efêmera melhora em 1931, seguida da queda dos indicadores em 1932, ano em que diversas firmas têxteis tiveram suas atividades afetadas pela Revolução Constitucionalista ${ }^{28}$. Estes anos foram pontuados por falências e paralisações de importantes empresas têxteis, conjuntura aproveitada pela Sociedade Anônima Fábrica Votorantim para aumentar sua capacidade produtiva através da compra de maquinário que seria de grande valia para os números crescentes da produção mesmo em cenário de crise. Para tanto, estes investimentos foram viabilizados pela adoção de uma medida administrativa que aponta para uma estratégia de financiamento calcada no capital próprio que, como veremos, complementava a participação dos capitais de terceiros. Entre 1921 e 1931, o Conselho Fiscal da SAFV aprovou, de forma contínua, a não distribuição de dividendos aos acionistas, medida indicada pela diretoria do grupo, que era controlada por Antonio Pereira Ignácio (diretor-presidente) e, a partir de julho de 1926, tinha também seu genro José Ermírio de Moraes (diretor-gerente), que se tornou o responsável pelas questões produtivas $^{29}$. Esta forma de financiamento ${ }^{30}$, que se valia do capital próprio do grupo, foi utilizada tendo como justificativa a necessidade de repor o maquinário que se tornava obsoleto no final da década de 1920. Principalmente, esta estratégia administrativa em meio à crise pode ser considerada como um fatorchave ao crescimento do grupo nos anos 1930, quando o acréscimo de maquinário representou uma elevação de capital investido que posicionaria a SAFV como a maior firma têxtil paulista ${ }^{31}$.

Tabela 4: Número de operários, teares, fusos e força motriz (em cavalo-elétrico) da Fábrica Têxtil Votorantim em relação ao ramo algodoeiro paulista, 1928-1931

\begin{tabular}{|c|c|c|c|c|c|c|c|c|}
\hline & \multicolumn{2}{|c|}{1928} & \multicolumn{2}{c|}{1929} & \multicolumn{2}{c|}{1930} & \multicolumn{2}{c|}{1931} \\
\hline & SAFV & $\begin{array}{c}\text { Setor Algodoeiro } \\
\text { Paulista (\%) }\end{array}$ & SAFV & $\begin{array}{c}\text { Setor Algodoeiro } \\
\text { Paulista (\%) }\end{array}$ & SAFV & $\begin{array}{c}\text { Setor Algodoeiro } \\
\text { Paulista (\%) }\end{array}$ & $\begin{array}{c}\text { Setor Algodoeiro } \\
\text { SAFV }\end{array}$ & \begin{tabular}{c} 
Paulista (\%) \\
\hline Operários
\end{tabular} \\
\hline 3.400 & 7,33 & 2.455 & 8,38 & 2.269 & 8,77 & 2.817 & 7,95 \\
\hline Teares & 1.300 & 5,69 & 1.390 & 5,58 & 1.466 & 5,62 & 1.498 & 6,02 \\
\hline Fusos & 47.340 & 6,48 & 70.020 & 8,48 & 70.020 & 8,57 & 69.628 & 8,46 \\
\hline Força Motriz & 3.400 & 7,25 & 4.000 & 7,43 & 4.000 & 7,97 & 4.000 & 7,53 \\
\hline
\end{tabular}

Fonte: DEIC/SAIC/SP. Estatística Industrial do Estado de São Paulo, 1928-1931.

Conforme a tabela 4, vemos que, apesar da conjuntura adversa da Crise de 1929 - que explica a derrocada no número de operários da empresa -, a quantidade de teares aumentou de 1.300 em 1928 para 1.498 três anos depois, bem como os fusos utilizados para elaboração dos fios de algodão. Estas máquinas

\footnotetext{
${ }^{27}$ No Relatório da Diretoria da SAFV para o ano de 1930 há o relato dos efeitos adversos deflagrados a partir Crise de 1929: “O ano de 1930 não correu bem para a indústria, em geral, tendo sido mau para a indústria têxtil, em particular. As diversas flutuações cambiais, ocorridas durante o ano e principalmente a crise que assoberba o País inteiro, trouxeram muita instabilidade nos negócios. As inúmeras falências verificadas no decorrer de 1930 também influíram consideravelmente na marcha dos negócios, causando prejuízos às casas atacadistas de tecidos e às fábricas" (SÃO PAULO. Diário Oficial do Estado de São Paulo, 22/03/1931, p. 2327).

${ }^{28}$ Em 1932, o capital investido nas firmas algodoeiras, que era aproximadamente $20 \%$ menor do que em 1928 , caiu $3,7 \%$ em relação a 1931; da mesma forma, a força motriz declinou 3\% entre 1931 e 1932, juntamente com a queda do número de fábricas que foi de 1,2\%. Quanto ao valor real da produção e o número de operários, em que pese apresentarem leve melhora entre 1931-1932, estes indicadores eram 22,7\% e 19,4\%, respectivamente, menores que em 1928 (Loureiro, 2006, p. 65).

${ }^{29}$ O pernambucano José Ermírio de Moraes, formado em engenharia de minas pela Colorado School of Mines (EUA), casouse com Helena Pereira Ignácio (filha de Antonio) no dia 18 de maio de 1925 na cidade de São Paulo (Caldeira, 2007, p. 52).

${ }^{30}$ Acerca da não distribuição de dividendos como forma de financiamento da empresa ver Penrose (2006, p. 67-68).

31 (SÃO PAULO. Diário Oficial do Estado de São Paulo, 15/08/1922, p. 1222; 15/02/1923, p. 1184; 14/02/1925, p. 1233; 12/02/1926, p. 1243; 15/02/1928, p. 1471; 23/02/1930, p. 1995; 22/03/1931, p. 2327; 25/02/1932, p. 15). No Relatório da Diretoria referente ao ano de 1929 consta "Atento aos constantes melhoramentos que vimos introduzindo nos diversos ramos, que constituem, em conjunto os fins e objetivos da Sociedade, não é aconselhável a distribuição de dividendos. A remodelação e aperfeiçoamento do maquinário exigiu o dispêndio de quantia avultada, que de futuro estamos certos, compensarão vantajosamente o sacrifício do presente” (SÃO PAULO. Diário Oficial do Estado de São Paulo, 23/02/1930, p. 1995).
} 
implicaram em maior utilização de energia elétrica - gerada por usina própria -, sendo a Fábrica Votorantim responsável pela utilização de quase $8 \%$ da força motriz na indústria algodoeira paulista. A ampliação no capital fixo possibilitou à Fábrica Votorantim tornar-se a principal empresa têxtil paulista, segundo o volume do capital investido, saindo da quarta posição em 1928 ao primeiro lugar em 1931, conforme a tabela 5 abaixo.

Tabela 5: As maiores firmas têxteis do Estado de São Paulo, 1928-1932 - segundo o capital investido

\begin{tabular}{|c|c|c|c|}
\hline \multicolumn{4}{|c|}{1928} \\
\hline FIRMA OU COMPANHIA & LOCAL & CAPITAL (em mil réis) & SETOR \\
\hline Companhia Nacional de Tecidos de Juta & Capital & 44.000 .000 & tecidos de juta \\
\hline Companhia Nacional de Tecidos de Juta & Capital & 26.000 .000 & tecidos de algodão \\
\hline Cotonifício Rodolpho Crespi S. A. & Capital & 22.936 .000 & tecidos de algodão \\
\hline Soc. Anon. Fábrica Votorantim & Sorocaba & 20.000 .000 & tecidos de algodão \\
\hline Companhia Nacional de Estamparia & Sorocaba & 19.248 .000 & tecidos de algodão \\
\hline \multicolumn{4}{|c|}{1929} \\
\hline Companhia Nacional de Tecidos de Juta & Capital & 48.578 .000 & tecidos de juta \\
\hline Soc. Anon. Fábrica Votorantim & Sorocaba & 34.921 .000 & tecidos de algodão \\
\hline Tecelagem de Seda Ítalo-Brasileira & Capital & 28.950 .000 & tecidos de seda \\
\hline Companhia Nacional de Tecidos de Juta & Capital & 26.000 .000 & tecidos de algodão \\
\hline Companhia Nacional de Estamparia & Sorocaba & 25.215 .000 & tecidos de algodão \\
\hline \multicolumn{4}{|c|}{1930} \\
\hline Cotonifício Scarpa S. A. & Capital & 60.000 .000 & tecidos de algodão \\
\hline Companhia Nacional de Tecidos de Juta & Capital & 40.000 .000 & tecidos de juta \\
\hline Soc. Anon. Fábrica Votorantim & Sorocaba & 34.236 .549 & tecidos de algodão \\
\hline São Paulo Alpargatas Company S. A. & Capital & 23.762 .600 & tecidos de algodão \\
\hline Companhia Nacional de Estamparia & Sorocaba & 22.803 .660 & tecidos de algodão \\
\hline \multicolumn{4}{|c|}{1931} \\
\hline Soc. Anon. Fábrica Votorantim & Sorocaba & 38.671 .849 & tecidos de algodão \\
\hline Companhia Nacional de Tecidos de Juta & Capital & 37.000 .000 & tecidos de juta \\
\hline Companhia Nacional de Estamparia & Sorocaba & 24.411 .000 & tecidos de algodão \\
\hline São Paulo Alpargatas Company S. A. & Capital & 23.413 .000 & tecidos de algodão \\
\hline Tecelagem de Seda Ítalo-Brasileira & Capital & 22.572 .000 & tecidos de seda \\
\hline \multicolumn{4}{|c|}{1932} \\
\hline Companhia Nacional de Tecidos de Juta & Capital & 37.000 .000 & tecidos de juta \\
\hline Companhia Nacional de Estamparia & Sorocaba & 27.084 .000 & tecidos de algodão \\
\hline São Paulo Alpargatas Company S. A. & Capital & 24.700 .000 & tecidos de algodão \\
\hline Soc. Anon. Fábrica Votorantim & Sorocaba & 23.614.671 & tecidos de algodão \\
\hline S. A. Tecelagem de Seda Ítalo-Brasileira & Capital & 22.572 .000 & tecidos de seda \\
\hline
\end{tabular}

Fonte: DEIC/SAIC/SP. Estatística Industrial do Estado de São Paulo, 1928-1932.

Nos anos 1930, a recuperação do setor têxtil nacional e paulista ganharia corpo a partir de 1933, como resultado da maturação de algumas medidas conjunturais: desvalorização real do câmbio em 19301931 que encareceu os preços dos artigos importados; elevação das tarifas de importação dos tecidos e fios de algodão em 1929; decreto 19.739, de março de 1931, que proibia a importação de novas máquinas têxteis e de outros setores; além do controle sobre as divisas (Suzigan, 2000, p. 162-163; Stein, 1979, p. 145). Estas medidas ajudariam na recuperação do setor têxtil paulista a partir de 1933, ano em que todos os indicadores do setor apresentaram crescimento - número de operários, capital, valor da produção e 
força motriz -, mantendo-se esta conjuntura favorável ao setor até o final dos anos 1930, sendo que o índice de crescimento das firmas têxteis foi 6,5\% entre 1933-1939, contrabalançando a retração de $-4,1 \%$ entre 1928-1932 (Suzigan, 1971, p. 99; Loureiro, 2006, p. 101).

A Fábrica Votorantim alcançou a liderança do setor têxtil paulista em meio ao contexto da Depressão Econômica dos anos 1930. A crise serviu para desestruturar os concorrentes ${ }^{32}$ da firma sorocabana que, pelo contrário, ampliou sua capacidade produtiva e consolidou sua posição de destaque no decorrer do decênio, alcançando novamente a liderança no setor nos anos de 1935-1937, como demonstra tabela 6.

Tabela 6: As maiores firmas têxteis do Estado de São Paulo, 1934-1937 - segundo o capital investido

\begin{tabular}{|c|c|c|c|}
\hline \multicolumn{4}{|c|}{1934} \\
\hline $\begin{array}{r}\text { FIRMA OU COMPANHIA } \\
\end{array}$ & LOCAL & $\begin{array}{l}\text { CAPITAL }(\text { em } \\
\text { mil réis })\end{array}$ & SETOR \\
\hline Companhia Nacional de Tecidos de Juta & Capital & 110.197 .000 & tecidos de juta \\
\hline Soc. Anon. Fábrica Votorantim & Sorocaba & 67.091 .939 & tecidos de algodão \\
\hline Companhia Nacional de Estamparia & Sorocaba & 43.721 .883 & tecidos de algodão \\
\hline Fiação, Tecelagem e Estamparia Ypiranga "Jafet" S. A. & Capital & 36.741 .410 & tecidos de algodão \\
\hline S. A. Tecelagem de Seda Ítalo-Brasileira & Capital & 35.994 .036 & tecidos de seda \\
\hline \multicolumn{4}{|c|}{1935} \\
\hline Soc. Anon. Fábrica Votorantim & Sorocaba & 68.928 .060 & tecidos de algodão \\
\hline Cotonifício Rodolpho Crespi S. A. & Capital & 58.232 .694 & tecidos de algodão \\
\hline S. A. Tecelagem de Seda Ítalo-Brasileira & Capital & 47.631 .707 & tecidos de seda \\
\hline Indústrias Reunidas Francisco Matarazzo & Capital & 37.936 .328 & tecidos de algodão \\
\hline Fiação, Tecelagem e Estamparia Ypiranga "Jafet" S. A. & Capital & 37.520 .842 & tecidos de algodão \\
\hline \multicolumn{4}{|c|}{1936} \\
\hline Soc. Anon. Fábrica Votorantim & Sorocaba & 68.928 .060 & tecidos de algodão \\
\hline Companhia Brasileira de Linhas para Coser S/A & Capital & 45.901 .179 & $\begin{array}{l}\text { cordas, cordéis, barbantes, fitilhos e } \\
\text { linhas para coser e bordar }\end{array}$ \\
\hline S. A. Tecelagem de Seda Ítalo-Brasileira & Capital & 40.538 .861 & tecidos de seda \\
\hline Indústrias Reunidas Francisco Matarazzo & Capital & 37.261 .334 & tecidos de algodão \\
\hline Indústrias Reunidas Francisco Matarazzo & $\begin{array}{c}\text { São } \\
\text { Bernardo } \\
\end{array}$ & 36.614 .014 & tecidos de seda \\
\hline \multicolumn{4}{|c|}{1937} \\
\hline Soc. Anon. Fábrica Votorantim & Sorocaba & 61.641.365 & tecidos de algodão \\
\hline Companhia Nitro-Química Brasileira & $\begin{array}{c}\text { São } \\
\text { Miguel } \\
\end{array}$ & 59.000 .000 & tecidos de seda \\
\hline Companhia Brasileira de Linhas para Coser S/A & Capital & 54.224 .239 & $\begin{array}{l}\text { cordas, cordéis, barbantes, fitilhos e } \\
\text { linhas para coser e bordar }\end{array}$ \\
\hline S. A. Tecelagem de Seda Ítalo-Brasileira & Capital & 39.109 .443 & tecidos de seda \\
\hline Fiação, Tecelagem e Estamparia Ypiranga "Jafet" S. A. & Capital & 35.000 .000 & tecidos de algodão \\
\hline
\end{tabular}

Fonte: DEIC/SAIC/SP. Estatística Industrial do Estado de São Paulo, 1934-1937.

De modo geral, a expansão da Fábrica Votorantim nos anos 1930 contou com elementos econômicos que também se fizeram presentes às congêneres naquela década: um mercado interno

${ }^{32}$ Os efeitos da crise econômica iniciada em 1929 serviram para abalar os negócios de algumas empresas têxteis paulistas em 1930, caso da Tecelagem Ítalo-Brasileira que estava extremamente endividada em 1930; do Cotonifício Scarpa que faliu naquele ano; e da São Paulo Alpargatas que chegou a entrar com pedido de falência, mas conseguiu renegociar suas dívidas e se manter em funcionamento. Devemos acrescentar que em 1935 entraria em falência aquela que foi a maior firma têxtil paulista por cinco vezes entre 1928-1934, a Companhia Nacional de Estamparia, como decorrência da diminuição na demanda por sacaria para o café e outros produtos (Loureiro, 2006, p. 66 e 113; Suzigan, 2000, p. 170). 
protegido - tarifas alfandegárias mais altas, câmbio desvalorizado e proibição à importação de maquinário - e o uso mais intensivo do maquinário, fatores que permitiram à produção têxtil algodoeira paulista crescer 58\% entre 1931-1937, ao passo que a produção nacional se expandiu em 50\% no mesmo período (Cano, 1981, p. 292; Stein, 1979, p. 152) ${ }^{33}$. Porém, existiram especificidades no processo de crescimento da Votorantim que são desnudadas a partir da análise de seus balanços financeiros a indicar outros fatores de crescimento do SAFV, além do aumento da capacidade instalada através da nãodistribuição de dividendos.

\section{4 - Os fatores de crescimento da Sociedade Anônima Fábrica Votorantim}

Analisando os indicadores patrimoniais da Sociedade Anônima Fábrica Votorantim (tabela 7 abaixo) nas décadas de 1920 e 1930, podemos dividir o evolver da SAFV em duas fases: 1) dificuldades entre 1929-1932, quando os efeitos da Depressão Econômica no setor têxtil transparecem através de um aumento real do passivo (crescimento acumulado de 100,24\%) em bases maiores que do ativo (crescimento acumulado de 83,19\%) e patrimônio líquido (crescimento acumulado 53,22\%); 2) expansão entre 1933-1939, marcada pelo avanço do ativo (crescimento acumulado de $288,12 \%$ ) e, principalmente, do patrimônio líquido (crescimento acumulado 380,18\%), frente a um menor aumento passivo (crescimento acumulado 235,75\%). Em que pese estes dois momentos, percebemos que a SAFV teve uma boa condição de solvência por todo o período, notada pelo quociente de cobertura total (ativo permanente mais ativo circulante, dividido pelo passivo circulante) - maior que 1 em toda a série - a mostrar que para cada unidade monetária de dívidas havia mais do que 1 unidade de ativos reais para quitá-las, demonstrando robustez do grupo econômico mesmo com as adversidades da Crise de 1929.

Tabela 7: Indicadores patrimoniais e financeiros da Sociedade Anônima Fábrica Votorantim, 19271939

\begin{tabular}{|c|c|c|c|c|c|c|c|c|c|c|c|}
\hline Anos & 1927 & 1929 & 1930 & 1931 & 1932 & 1933 & 1934 & 1935 & 1936 & 1938 & 1939 \\
\hline $\begin{array}{l}\text { Variação real do Ativo (\%) } \\
\text { ano-base } 1924\end{array}$ & 26,08 & 2,54 & 15,19 & 33,38 & 32,08 & 35,05 & 39,48 & 51,86 & 40,86 & 55,09 & 65,78 \\
\hline $\begin{array}{l}\text { Variação real do Passivo (\%) } \\
\text { ano-base } 1924\end{array}$ & 9,86 & 8,84 & 21,49 & 36,98 & 32,93 & 32,16 & 40,26 & 56,82 & 30,26 & 35,44 & 40,81 \\
\hline $\begin{array}{l}\text { Variação real do Patrimônio líquido (\%) } \\
\text { ano-base } 1924\end{array}$ & 54,45 & $-8,53$ & 4,11 & 27,04 & 30,60 & 40,13 & 38,10 & 43,13 & 59,50 & 89,63 & 109,69 \\
\hline Quociente Cobertura Total & 1,811 & 1,478 & 1,497 & 1,542 & 1,558 & 1,646 & 1,515 & 1,586 & 1,676 & 1,825 & 1,847 \\
\hline Liquidez Corrente & 0,652 & 0,646 & 0,651 & 0,687 & 0,659 & 0,661 & 0,558 & 0,434 & 0,441 & 0,793 & 0,802 \\
\hline$\%$ Capital de Terceiros no Ativo Total & 55,2 & 67,7 & 66,8 & 64,8 & 64,1 & 60,7 & 66 & 63 & 59,6 & 54,8 & 54,1 \\
\hline \% Capital Próprio no Ativo Total & 44,8 & 32,3 & 33,2 & 35,2 & 35,8 & 37,2 & 35,9 & 34 & 41,7 & 44,2 & 45,9 \\
\hline Imobilização do Capital & 1,427 & 1,739 & 1,702 & 1,576 & 1,609 & 1,607 & 1,533 & 2,137 & 1,767 & 1,276 & 1,234 \\
\hline
\end{tabular}

Fonte: Os índices foram elaborados pelo autor com base no Anexo I.

Nota: para obter a variação real das contas do balanço (ativo, passivo e patrimônio líquido) foi utilizado o Deflator Implícito do PIB elaborado pelo ipeadata (http://www.ipeadata.gov.br/) com base no trabalho de Haddad, Claudio Luiz da Silva. Crescimento do produto real no Brasil, 1900-1947. Rio de Janeiro: Fundação Getúlio Vargas, 1978.

Tendo em conta que a ampliação da capacidade produtiva da Fábrica Votorantim deu-se em um momento de severa crise econômica, uma das questões fundamentais a ser resolvida pela empresa era o financiamento que, no caso da SAFV, advinha, em sua maioria, dos capitais de terceiros, constituindo-se em um fator-chave ao crescimento do Grupo Votorantim no período. Através da análise da tabela 7 acima, vemos que, nestes decênios, o financiamento dava-se prioritariamente através do capital de

\footnotetext{
${ }^{33}$ Stein (1979, p. 148-152) aponta que as restrições à importação de máquinas têxteis estimularam o surgimento de algumas firmas nacionais produtoras de teares que, junto da revenda de teares usados, respondiam pela ampliação de capacidade instalada de algumas firmas têxteis, caso da Fábrica Votorantim que, em 1931, tinha 1.498 teares, número que aumentou para 1.580 teares nos anos 1933-1937. Além dos teares, a Fábrica Votorantim contava com 67 mil fusos nos anos 1937.
} 
terceiros (passivo circulante dividido pelo ativo total), sendo que, entre 1929-1935, eles tiveram uma participação média de $65 \%$ em relação ao ativo total, enquanto $35 \%$ vinham de capital próprio (patrimônio líquido dividido pelo ativo total). Uma das explicações para a obtenção destes capitais como o empréstimo externo levantado em Londres em 1926 e que se tornou a maior conta do passivo até ser quitado em 1938 - estava nos nexos entre a Votorantim e grandes financistas, já que, entre 1922-1931, o grupo tinha os seguintes membros em seu Conselho Fiscal: Manoel de Barros Loureiro; Araújo Costa \& Cia.; e o Banco do Comércio e Indústria do Estado de São Paulo (Comind), representado em alguns dos relatórios por Numa de Oliveira, presidente de seu Conselho Administrativo ${ }^{34}$. Este banco, a principal casa bancária nacional a atuar no Estado de São Paulo nos anos 1920, caracterizava-se pela participação de seus diretores na diretoria de outras companhias, tendo a casa forte atuação no financiamento do grande capital cafeeiro paulista ${ }^{35}$, em uma simbiose entre grupos econômicos e instituições financeiras que garantia a provisão de capital aos negócios industriais, inclusive nas conjunturas econômicas adversas (Granovetter, 2005, p. 434) ${ }^{36}$.

A necessidade de recursos de terceiros explicava-se pelos valores elevados do indicador de imobilização do capital (ativo permanente dividido pelo patrimônio líquido), uma vez que, um valor equivalente a $160 \%$ do patrimônio líquido estava investido no ativo permanente entre 1927-1934, ou seja, boa parte do capital próprio da empresa encontrava-se imobilizado. Esta peculiaridade é corroborada pelo indicador de liquidez corrente (ativo circulante dividido pelo passivo circulante), pois para cada unidade de dívida de curto prazo, a SAFV tinha em média 0,7 unidades monetárias de ativos de curto prazo (disponibilidades) para quitar o débito. No que tange à solvência do grupo, notamos que isto não se traduziu em problemas de maior vulto, pois mesmo que a baixa liquidez corrente pudesse indicar um problema de solvência no curto prazo, todavia, o elevado montante de capital imobilizado poderia servir como garantia à obtenção de empréstimos bancários e demais captações junto a terceiros, o que garantiu a evolução dos negócios da SAFV em conjunto a uma estável condição de solvência indicada pelo quociente de cobertura total, como visto acima.

De fato, a elevada imobilização de capital era uma condição estrutural da SAFV e que advinha do fato de ser um grupo econômico, ou seja, vários empreendimentos - presentes no ativo da SAFV - que compunham uma só estrutura empresarial, configurando-se esta condição de grupo econômico outro fator-chave para o crescimento da Votorantim no Entreguerras, pois cada um destes empreendimentos geravam novas oportunidades de ganho ou ampliavam os lucros das demais empresas do grupo. Por exemplo, conforme visto na tabela 2, no ano de 1927, a Fábrica Votorantim (têxtil) gerou $68 \%$ das receitas do grupo - uma queda em relação ao seu patamar médio de $80 \%$-, enquanto a Seção de Terrenos respondeu por 13,3\%, a Estrada de Ferro Elétrica por 13,7\%, as Caieiras de Itupararanga por 4,2\% e a Fábrica de Cimento Rodovalho por 0,8\%. Naquele momento, a SAFV tinha um grande empreendimento imobiliário na cidade de São Paulo, baseado na venda de seus terrenos no loteamento Brooklyn Paulista (atualmente Brooklyn Velho), iniciado em 1922. Conforme anúncio no jornal sorocabano O Cruzeiro do Sul em 1925, a SAFV vendia os terrenos a prestações sem juros e, ademais, por produzir materiais de construção - cal, cimento e tijolos em Itupararanga e Rodovalho - podia fornecê-los a preços menores, o que, segundo a publicação, era motivo da grande procura pelos terrenos e, para os negócios do grupo, uma fonte de receitas que unia seus empreendimentos paralelos (SAFV, 1925).

\footnotetext{
34 (SÃO PAULO. Diário Oficial do Estado de São Paulo, 15/02/1923, p. 1184; 14/02/1925, p. 1233; 12/02/1926, p. 1243; 15/02/1928, p. 1471; 23/02/1930, p. 1995; 22/03/1931, p. 2327; 25/02/1932, p. 15).

${ }^{35}$ Em 1907, Antonio Prado e Francisco Antonio de Souza Queiroz eram diretores do Banco do Comércio e Indústria de São Paulo e também da Companhia Paulista de Estradas de Ferro. Ademais, J. Álvares Rubião Junior e J. Queiroz Lacerda eram diretores do banco e conselheiros da ferrovia, junto com Bento José de Carvalho, que era conselheiro nas duas firmas (Saes, 1986, p. 136).

${ }^{36}$ As fontes de financiamento à indústria nacional, em que pese a carência de um banco de desenvolvimento antes de 1952 , podiam vir do lançamento de debêntures e ações na Bolsa de Valores de São Paulo e do Rio de Janeiro, dos empréstimos concedidos pelos bancos, caso dos empréstimos hipotecários, e, também, dos capitais próprios. Houve uma expansão destas formas de crédito, que prescindiam da atuação estatal, entre 1890-1930, marcada, por exemplo, pelo aumento no número de empresas listadas nas Bolsas de Valores, sendo que 8,6\% do capital negociado na Bolsa de São Paulo em 1917 era proveniente de firmas têxteis (Hanley, 2005, p. 103; Marcondes, 2014, p. 759-782; Musacchio, 2009, p. 81).
} 
Nesta mesma perspectiva de um grupo econômico, em 1931 a produção têxtil da Fábrica Votorantim valia-se dos trilhos da Estrada de Ferro Elétrica Votorantim, que desde julho de 1928 fazia parte da rede ferroviária estadual, sendo que "Não é pequena a vantagem da circulação facilitada assim dos produtos da Sociedade Anônima Fábrica Votorantim" (SÃO PAULO. Diário Oficial do Estado de São Paulo, 25/02/1932, p. 15). Acerca da Fábrica Rodovalho, corria a extração de paralelepípedos, que atendeu à demanda de três localidades em 1931, além de fornecer à SAFV. Ademais, continuava a exploração de cal virgem e extinta nas Caieiras de Itupararanga ${ }^{37}$ - que também atendia à Fábrica Votorantim -, bem como a venda de terrenos em São Caetano e no Brooklyn Paulista.

Os nexos produtivos entre as empresas do grupo SAFV, que já exibiam seu papel relevante nos resultados do grupo nos anos 1920, foram ampliados no decorrer da década de 1930, tendo como premissas a integração produtiva na cadeia têxtil e a diversificação de atividades como fontes para o crescimento econômico do grupo (Chandler, 1998, p. 72 e 170; Penrose, 2006, p. 170-171). Tomando por base a Estatística Industrial do Estado de São Paulo em 1929, a Sociedade Anônima Fábrica Votorantim era detentora, além da fábrica têxtil, de apenas outra firma: a Caieiras de Santa Helena (ou Itupararanga) que produziam cal e, como subproduto, adubos (DEIC/SAIC/SP. Estatística Industrial do Estado de São Paulo, 1929, p. 19 e 67).

No setor têxtil, a SAFV aprofundou sua integração produtiva, pois, no ano de 1931, em meio à crise que se abateu sobre a lavoura e a indústria, o grupo decidiu financiar plantadores de algodão da região de Sorocaba e zonas próximas a fim de garantir o fornecimento de matéria-prima que, por sua vez, era beneficiada em instalações próprias nas cidades de Cerqueira César, Itapetininga, Avaré e Conchas, possibilitando à Fábrica Votorantim superar seu recorde de produção ${ }^{38}$. Em 1937, esta prática já havia sido replicada pelo grupo com a construção de outra usina de algodão na cidade de Espírito Santo do Pinhal, ou seja, a principal firma têxtil paulista tinha como um de seus vetores de crescimento a obtenção garantida de matéria-prima às suas atividades, ao articular-se com produtores e, ademais, montar estruturas para beneficiamento da fibra ${ }^{39}$. Além do setor têxtil, a SAFV iniciou em terras sorocabanas, no ano de 1933, a construção da Fábrica de Cimento Santa Helena, que foi inaugurada em 1934 para produzir o Cimento Votoran, com um forno importado da Dinamarca. Os sacos de cimento eram levados de Sorocaba para os mercados consumidores, sobretudo a cidade de São Paulo, pelos trilhos da Estrada de Ferro Votorantim, tornando-se nova e importante fonte de receitas ao Grupo ${ }^{40}$.

Dessa forma, na Estatística Industrial do Estado de São Paulo de 1937, a SAFV aparecia em variados setores:

- Fábrica Votorantim (Sorocaba-SP): fiação e tecelagem de algodão com a Fábrica Votorantim (capital de 61 contos e 3.500 operários para a produção de fios estampados, crus e tintos) e outra unidade na cidade de Espírito Santo do Pinhal (capital de 500 contos de réis e 214 operários que cuidavam da fiação); óleos vegetais e sub-produtos na Fábrica Votorantim (capital de 670 contos de réis e 321 operários para a produção de óleo de semente de algodão, linter, torta e estearina); sabão e saponáceo na Fábrica Votorantim (capital de 120 contos e 18 operários para a produção de sabão comum; olarias com a Fábrica Votorantim em Sorocaba (capital 10 contos de réis e 18 operários para a fabricação de tijolos);

\footnotetext{
${ }^{37}$ A empresa Caieiras de Itupararanga, localizada em Sorocaba e pertencente ao Grupo Votorantim, era segunda firma em volume de capital (1.071 contos de réis), empregando 78 operários, com uma força-motriz de 2 cavalos-elétricos e possuindo 1 forno para produção de cal. Nesta época, o setor de cal e cimento paulista era dominado pela Companhia Brasileira de Cimento Portland S. A. que, em 1931, tinha um capital de 25.000 contos de réis, empregava 481 trabalhadores, tinha forçamotriz de 7.072 cavalos-elétricos e possuía 3 fornos que produziam cimento (DEIC/SAIC/SP. Estatística Industrial do Estado de São Paulo, 1931).

${ }^{38}$ (SÃO PAULO. Diário Oficial do Estado de São Paulo, 25/02/1932, p. 15). No Relatório da Diretoria para o ano de 1931 constava que "A fábrica de tecidos de algodão e seda de Votorantim operou no máximo de sua capacidade".

${ }^{39}$ O Relatório da Diretoria da SAFV para o ano de 1931 (SÃO PAULO. Diário Oficial do Estado de São Paulo, 25/02/1932, p. 15) dizia que a "A Sociedade Anônima Fábrica Votorantim procura de modo positivo dentro de sua atividade peculiar, ajustar em um só complexo econômico a produção agrícola e a industrial".

${ }^{40}$ Em 1938, a Votorantim teve um impulso na demanda por cimentos ao vencer a licitação para remodelação do Viaduto do Chá, na cidade de São Paulo, obra em que foi utilizado o Cimento Votoran (Caldeira, 2007, p. 81).
} 
- Fábrica de Cimento Santa Helena (Sorocaba-SP): cimento e cal com a Fábrica Santa Helena (capital de 15 mil contos e 664 operários para a fabricação de cimento); adubos e colas nas Caieiras de Santa Helena (capital de 5 contos de réis e 4 operários para a produção de adubos de origem mineral);

- Fábrica Rodovalho (São Roque-SP): cimento e cal com a Fábrica Rodovalho (capital de 180 contos e 23 operários para extração de cal);

- Oficinas de estradas de ferro com a oficina da E. F. Votorantim (situada em Sorocaba, com capital de 30 contos de réis e 63 operários para reparos de bondes e vagões);

- Usina do Itupararanga (Sorocaba-SP): energia elétrica com a usina na Represa do Itupararanga (com capital total de 420 contos e 42 operários) para fornecimento de energia às fábricas do grupo, bem como venda de energia às localidades próximas (DEIC/SAIC/SP. Estatística Industrial do Estado de São Paulo, 1937, p. 45, 126, 157, 174, 196, 198, 199 e 246).

No decorrer dos anos 1930, a SAFV calcada em sua ampla capacidade produtiva, nos capitais de terceiros e na acumulação gerada pelos diversos empreendimentos, além da recuperação da economia brasileira e de seus efeitos positivos à demanda têxtil, expandiu-se e pôde, inclusive, quitar seu empréstimo em Londres em 1937 - cujo vencimento era apenas para o ano de 1946. Neste final de decênio - conforme demonstra o balanço patrimonial no anexo 2 - a SAFV contava com maior participação de capital próprio como proporção do ativo total, a demonstrar a lucratividade do grupo econômico que, dentre seus ativos, possuía a Fábrica Votorantim, a principal empresa têxtil do Estado de São Paulo.

\section{Considerações finais}

$\mathrm{O}$ artigo buscou evidenciar os elementos fundamentais que levaram a Sociedade Anônima Fábrica Votorantim a tornar-se a maior firma têxtil paulista na década de 1930. O ponto de partida desta trajetória foi a compra por Antonio Pereira Ignácio da Fábrica Votorantim e as demais empresas componentes do grupo (Caieiras de Itupararanga e Estrada de Ferro Elétrica Votorantim), aos quais ele agregou a Fábrica de Cimento Rodovalho, compondo o grupo econômico SAFV.

Através do controle acionário de Pereira Ignácio e da visão estratégica de José Ermírio de Moraes, o Grupo Votorantim adotou a política de não-distribuição de dividendos por toda a década de 1920 e início dos anos 1930. Esta medida administrativa ampliou as reservas do grupo que, em meio à crise econômica entre 1929-1932, viu-se munido do capital próprio para aproveitar uma conjuntura em que seus principais concorrentes soçobravam. Neste período, o grupo adquiriu novos teares e fusos, expandindo a capacidade produtiva da Fábrica Votorantim, o que permitiu alcançar um recorde na produção de tecidos de algodão em 1931, primeiro ano em que a Votorantim tornou-se líder no setor têxtil paulista, segundo o capital investido.

Esta liderança, novamente atingida entre 1935-1937, teve também como fatores-chaves os capitais de terceiros e a organização como grupo econômico. Sobre aos capitais de terceiros, eles se constituíram como a maior fonte de capitalização ao grupo durante todo o período analisado, destacando-se o empréstimo obtido em Londres no ano de 1926 e que veio a reforçar as finanças do grupo antes de 1929, quando escasseariam as fontes institucionais de crédito.

Em relação à constituição como grupo econômico, a SAFV conseguia vincular seus diversos empreendimentos no intuito de permitir com que cada um deles gerasse renda e reforçasse a acumulação dos outros ativos. Da ferrovia que transportava os tecidos e os sacos de cimento aos mercados consumidores, passando pela usina própria que alimentava as instalações fabris na região de Sorocaba, nota-se que a SAFV formou um grupo de ativos integrado e diversificado, concentrado no setor têxtil paulista, mas com presença nos ramos de cimento e cal, olarias, adubos, sabão, óleos vegetais, oficinas de trem e energia elétrica. Estes empreendimentos eram fundamentais à unidade têxtil, pois diminuíam seus custos, por exemplo, relativos ao transporte e aquisição de matéria-prima, permitindo à Fábrica Votorantim consolidar-se como a maior firma têxtil do Estado de São Paulo nos anos 1930.

Por fim, é relevante notar que se atualmente o Grupo Votorantim é o maior conglomerado industrial de origem privada no Brasil, o início desta trajetória baseou-se na liderança alcançada pelo grupo no setor 
têxtil paulista. A guinada da Votorantim ao setor industrial de base, no decorrer da década de 1930 e 1940, esteve alicerçada na acumulação gerada principalmente pela Fábrica Votorantim, a unidade têxtil do grupo. Os empreendimentos no setor siderúrgico (Siderúrgica Barra Mansa), setor químico (Cia. Nitroquímica), setor de cimento e cal (Cimento Votoran e Poty) e no setor de alumínio (Companhia Brasileira de Alumínio) valeram-se dos capitais gerados pelo principal investimento do grupo naqueles anos, a unidade têxtil sorocabana Fábrica Votorantim.

\section{Referências bibliográficas \\ Fontes primárias}

DEIC/SACOP/SP. Boletim da Diretoria de Indústria e Comércio para o ano de 1922. São Paulo: fevereiro e março de 1922.

DEIC/SAIC/SP. Estatística Industrial do Estado de São Paulo, 1928-1937.

EFEV. Breve histórico da Estrada de Ferro Elétrica Votorantim (EFEV). São Paulo: S. A. Indústrias Votorantim.

SAFV. Livro Diário da Sociedade Anônima Fábrica Votorantim (SAFV) para o ano de 1918-1919. São Paulo: Centro de Memória do Grupo Votorantim.

SAFV. Balanço da Sociedade Anônima Fábrica Votorantim para o ano de 1923. São Paulo: Centro de Memória do Grupo Votorantim.

SAFV. Anúncio publicitário no jornal O Cruzeiro do Sul sobre a venda de terrenos no Brooklyn Paulista, ano de 1925. São Paulo: Centro de Memória Votorantim.

SÃO PAULO. Diário Oficial do Estado de São Paulo, 1921-1940. Consulta aos balanços contábeis, demonstrações de lucros e perdas, e aos relatórios de diretoria da Sociedade Anônima Fábrica Votorantim.

\section{Demais referências}

ALDRIGHI, D. M. e POSTALI, F. A. S. Business groups in Brazil. In: COLPAN, A. M.; HIKINO, T.; LINCOLN, J. R. The Oxford Handbook of business groups. Oxford University Press, Oxford, 2010.

AURELIANO, L. No limiar da industrialização. Campinas, SP: UNICAMP/IE, 1999.

BAER, W. A industrialização e o desenvolvimento econômico do Brasil. Rio de Janeiro: Fundação Getúlio Vargas, 1975.

BAER, W. A economia brasileira. São Paulo: Nobel, 2002.

BARBERO, M. I. Los grupos económicos en la Argentina en una perspectiva de largo plazo (siglos XIX y XX).In: JONES, G.; LLUCH, A. El Impacto Histórico de la globalización en Argentina y Chile: empresas y empresarios. Buenos Aires: Temas, 2011.

BONELLI, R. As estratégias dos grandes grupos industriais brasileiros nos anos 90. Brasília: Ipea, Texto para Discussão 569, jul. 1998.

CALDEIRA, J. Votorantim 90 anos: uma história de trabalho e superação. São Paulo, SP: Mameluco, 2007.

CANO, W. Raízes da concentração industrial em São Paulo. T. A. Queiroz, 1981.

CANO, W. Da Década de 1920 à de 1930: Transição Rumo à Crise e à Industrialização no Brasil. Revista EconomiA, Brasília(DF), v.13, n. 3b, p.897-916, set/dez 2012.

CARONE, E. A evolução industrial de São Paulo (1889-1930). São Paulo: Editora Senac, 2001.

CHANDLER, A. D. Alfred Chandler: ensaios para uma teoria histórica da grande empresa. Organizado por Thomas K. McCraw. Rio de Janeiro: Editora da Fundação Getulio Vargas, 1998.

COLPAN, A. M. e HIKINO, T. Foundations of business groups: towards an integrated framework. In: In: COLPAN, A. M.; HIKINO, T.; LINCOLN, J. R. The Oxford Handbook of business groups. Oxford University Press, Oxford, 2010.

DEAN, W. A Industrialização de São Paulo. São Paulo: Difel, 1971.

FERNÁNDEZ-PEREZ, P. The study of family businesses from a global perspective: possibilities and limitations. História Econômica \& História de Empresas. São Paulo, v. 13, n. 2, p. 147-167, 2010.

FERNÁNDEZ-PEREZ, P. e CASANOVA, L. Algunas claves de la longevidad de las grandes empresas familiares brasileñas. Apuntes, Universidad del Pacífico, v. 39, n. 70, p. 273-300, $1^{\text {o }}$ semestre 2012. 
GONÇALVES, R. Grupos econômicos: uma análise conceitual e teórica. Revista Brasileira de Economia, Rio de Janeiro, v. 45, n. 4, p. 491-518, out./dez. 1991.

GONÇALVES, R. Capital financeiro, bancário e industrial no Brasil. Economia e Sociedade, Campinas, SP, (13), p. 179-189, dez. 1999.

GRANOVETTER, M. Business groups and social organization. In: SMELSER, N. J. e SWEDBERG, R. The handbook of economic sociology. Oxfordshire: Princeton University Press, Princeton, 2005.

HANLEY, A. G. Native capital: financial institutions and economic development in Sao Paulo, Brazil, 1850-1920. Stanford, Calif.: Stanford University, 2005.

KHANNA, T. e YAFEH, Y. Business Groups in Emerging Markets: Paragons or Parasites? Journal of Economic Literature, Vol. XLV, p. 331-372, junho 2007.

KIM, D.; KANDEMIR, D.; CAVUSGIL, S. T. The role of family conglomerates in emerging markets: what western companies should know. Thunderbird international business review, v. 46, p. 13 - 38, jan/feb 2004.

LEFF, N. Industrial organization and entrepreneurship in the developing countries: the economic groups. Economic development and cultural change, 26, 661-675, março, 1978.

LLOYD, R. et. al. Impressões do Brazil no século vinte. Londres: Lloyd's Greater Britain Plublishing Company, 1913.

LOUREIRO, F. P. Nos fios de uma trama esquecida: a indústria têxtil paulista nas décadas pósDepressão (1929-1950). São Paulo, 2007. Dissertação (Mestrado) - Faculdade de Filosofia, Letras e Ciências Humanas, Universidade de São Paulo.

LUZ, N. V. A luta pela industrialização do Brasil: 1808 a 1930. São Paulo: Alfa-Omega, 1975.

MARCONDES, R. L. Crédito privado antes da grande depressão do século XX: o mercado hipotecário. Estud. Econ. [online]. 2014, vol.44, n.4 [cited 2015-04-30], pp. 749-786.

MARCOVITCH, J. Pioneiros \& Empreendedores, volume 2. São Paulo: EDUSP, 2009.

MARSON, M. D. A industrialização brasileira antes de 1930: uma contribuição sobre a evolução da indústria de máquinas e equipamentos no estado de São Paulo, 1900-1920. Anais do $41^{\circ}$ Encontro Nacional de Economia, Anpec, Foz do Iguaçu, dezembro de 2013.

MELLO, J. M. C. O capitalismo tardio: contribuição à revisão crítica da formação e do desenvolvimento da economia brasileira. Campinas: Facamp/Editora da UNESP, 2009.

MUSACCHIO, A. Experiments in financial democracy: corporate governance and financial development in Brazil, 1882-1950. New York: Cambridge University Press, 2009.

NEGRI, B. Concentração e desconcentração industrial em São Paulo(1880-1990). Campinas: UNICAMP, 1996.

PENROSE, E. T. A teoria do crescimento da firma. Campinas, SP: Editora da UNICAMP, 2006.

RIBEIRO, M. A. R. Condições de trabalho na indústria têxtil paulista (1870-1930). São Paulo, SP: Hucitec: Editora da UNICAMP, 1988.

SAES, F. A. M. Crédito e bancos no desenvolvimento da economia paulista, 1850-1930. São Paulo: IPE/USP, 1986.

SANTOS, L. B. Reestruturação, internacionalização e novos territórios de acumulação do Grupo Votorantim. Presidente Prudente, SP: FCT/UNESP, dissertação de mestrado, 2008.

SILVA, S. Expansão cafeeira e origens da indústria no Brasil. 8.ed. São Paulo: Alfa-ômega, 1995.

STEIN, S. J. Origens e evolução da indústria têxtil no Brasil, 1850-1950. Rio de Janeiro: Campus, 1979.

SUZIGAN, W. A Industrialização de São Paulo: 1930-1945. Revista Brasileira de Economia. Rio de Janeiro, v. 25, n. 2, p. 89-111, 1971.

SUZIGAN, W. Indústria Brasileira: origem e desenvolvimento. São Paulo: Hucitec/ Ed. Unicamp, 2000.

VERSIANI, F. R. e VERSIANI, M. T. A indústria brasileira antes de 1930: uma contribuição. In: VERSIANI, F. R. e MENDONÇA DE BARROS, J. R. Formação econômica do Brasil. São Paulo: Saraiva, 1977.

VILlELA, A. V. e SUZIGAN, W. Política do governo e crescimento da economia brasileira, 1889 1945. Rio de Janeiro: IPRA/INPES, 1973. 
Anexo 1: Balanços Patrimoniais da S. A. Fábrica Votorantim, 1924-1931 (em contos de réis correntes)

\begin{tabular}{l} 
Anos \\
\hline Ativo Circulante \\
Caixa \\
Venda de terrenos \\
Selos de consumo \\
Devedores diversos \\
Clientes (Letras a receber) \\
Caução dos diretores \\
Estoque de mercadorias e matérias-primas
\end{tabular}

\section{Ativo Permanente}

Edifício da Fábrica, terrenos e vila operária, fábrica de cimento Rodovalho, caieiras de Itupararanga, Estrada de Ferro Elétrica Votorantim, maquinismos, ferramentas, utensílios, incluindo imóveis, etc.

Terrenos diversos e propriedades agrícolas

Debêntures em carteira

Ações

Acionistas

Móveis e utensílios

Despesas e prêmio de reembolso do empréstimo externo

Contas a liquidar

Seguros a vencer

Plantação de eucaliptos Brooklyn Paulista

\section{Ativo Total}

\section{Passivo Circulante}

Empréstimo externo

Emissão de debêntures

Diversos credores

Letras a Pagar

Títulos descontados e caucionados

Seção de terrenos

Serviços médicos

Porcentagem dos diretores

Salários a pagar

Depósito dos diretores

Debêntures sorteadas e juros não reclamados

Fundo de depreciação

Impostos

Diferença de tipo sobre o resgate antecipado de debêntures

Contas a liquidar

\section{Patrimônio Líquido}

Capital

Reservas

Lucros suspensos

Lucros e perdas

Passivo Total

\begin{tabular}{cccccc}
$\mathbf{1 9 2 4}$ & $\mathbf{1 9 2 5}$ & $\mathbf{1 9 2 7}$ & $\mathbf{1 9 2 9}$ & $\mathbf{1 9 3 0}$ & $\mathbf{1 9 3 1}$ \\
\hline $\mathbf{3 6 . 3 3 5}$ & $\mathbf{3 9 . 7 7 2}$ & $\mathbf{3 0 . 6 2 7}$ & $\mathbf{3 2 . 5 3 7}$ & $\mathbf{3 1 . 8 3 3}$ & $\mathbf{3 3 . 6 3 8}$ \\
88 & 65 & 196 & 50 & 78 & 90 \\
2.748 & 2.727 & 2.506 & 2.743 & 2.032 & 1.412 \\
2 & 0 & 0 & 0 & 1 & 1 \\
10.344 & 14.428 & 7.644 & 12.759 & 16.788 & 17.654 \\
9.513 & 8.398 & 7.865 & 7.766 & 6.194 & 7.884 \\
80 & 80 & 40 & 40 & 40 & 40 \\
13.560 & 14.074 & 12.376 & 9.179 & 6.700 & 6.557 \\
$\mathbf{3 4 . 7 1 3}$ & $\mathbf{3 5 . 6 4 6}$ & $\mathbf{5 4 . 3 6 0}$ & $\mathbf{4 1 . 8 1 3}$ & $\mathbf{4 1 . 3 5 7}$ & $\mathbf{4 1 . 8 8 9}$
\end{tabular}

$\begin{array}{cccccc}32.500 & 34.170 & 35.416 & 24.292 & 24.635 & 25.217 \\ 1.084 & 1.043 & 1.459 & 1.590 & 1.777 & 1.746 \\ 607 & 235 & & & & \\ 124 & 74 & 1.947 & 968 & 967 & 967 \\ & & 13.500 & 13.500 & 13.500 & 13.500 \\ & & 85 & & 56 & 25 \\ & & 1.691 & 1.463 & 359 & 168 \\ 398 & 124 & 262 & & 63 & 171 \\ & & & & & 82 \\ & & & & & 13\end{array}$

$\begin{array}{llllll}\mathbf{7 1 . 0 4 8} & \mathbf{7 5 . 4 1 8} & \mathbf{8 4} .987 & \mathbf{7 4 . 3 5 0} & \mathbf{7 3 . 1 9 0} & \mathbf{7 5 . 5 2 7}\end{array}$

$\begin{array}{cccccc}\mathbf{4 9 . 1 9 0} & \mathbf{5 1 . 1 7 6} & \mathbf{4 6 . 9 0 9} & \mathbf{5 0 . 3 0 4} & \mathbf{4 8 . 8 8 7} & \mathbf{4 8 . 9 5 4} \\ & & 15.026 & 14.921 & 14.236 & 17.236 \\ 1.834 & 1.435 & 1.435 & 1.435 & 1.435 & 1.435 \\ 21.729 & 20.230 & 11.569 & 23.412 & 25.863 & 23.423 \\ 9.982 & 14.818 & 10.343 & 970 & 703 & 190 \\ 8.935 & 8.355 & 6.509 & 6.966 & 4.883 & 4.854 \\ 1.554 & 1.434 & 1.123 & 2.141 & 1.237 & 407 \\ 50 & 26 & & 6 & 4 & 14 \\ 599 & 221 & 25 & 9 & 17 & 153 \\ 564 & 434 & 496 & 264 & 242 & 438 \\ 80 & 80 & 40 & 40 & 40 & 40 \\ & 3 & & & & \\ 3.863 & 4.140 & & & & \\ & & 208 & & 10 & 129 \\ & & 135 & 140 & 217 & 217 \\ & & & & & 418\end{array}$

21.917 $24.190 \quad 38.079 \quad 24.044 \quad 24.304 \quad 26.586$

$\begin{array}{llllll}5.000 & 5.000 & 20.000 & 20.000 & 20.000 & 20.000\end{array}$

$\begin{array}{llllll}11.519 & 11.796 & 17.762 & 3.927 & 3.984 & 4.818\end{array}$

5.398

$\begin{array}{llllll}5.398 & 1.996 & 317 & 117 & 320 & 1.768\end{array}$

$\begin{array}{llllll}\mathbf{7 1 . 1 0 7} & \mathbf{7 5 . 3 6} & \mathbf{8 4 . 9 8 8} & \mathbf{7 4 . 3 4 8} & \mathbf{7 3 . 1 9 1} & \mathbf{7 5 . 5 4 0}\end{array}$ 


\section{Indicadores financeiros}

Quociente Cobertura Total

$\begin{array}{cccccc}1,444 & 1,474 & 1,811 & 1,478 & 1,497 & 1,542 \\ 0,738 & 0,777 & 0,652 & 0,646 & 0,651 & 0,687 \\ 0,246 & 0,306 & 0,008 & 0,005 & 0,013 & 0,066 \\ 0,076 & 0,098 & 0,004 & 0,002 & 0,004 & 0,023 \\ 69,2 & 67,8 & 55,2 & 67,7 & 66,8 & 64,8 \\ 30,8 & 32,2 & 44,8 & 32,3 & 33,2 & 35,2 \\ 2,244 & 2,115 & 1,231 & 2,092 & 2,011 & 1,841 \\ 1,584 & 1,473 & 1,427 & 1,739 & 1,702 & 1,576\end{array}$

Liquidez Corrente

Quociente Rentabilidade Patrimônio Líquido

Quociente Rentabilidade do Ativo

$\%$ Capital de Terceiros no Ativo Total

$\%$ Capital Próprio no Ativo Total

Estrutura Capital: Participação Capital de Terceiros

$1,584 \quad 1,473 \quad 1,427 \quad 1,739 \quad 1,702 \quad 1,576$

Imobilização do Capital

Fonte: SÃO PAULO. Diário Oficial do Estado de São Paulo, 14/02/1925, p. 1233; 12/02/1926, p. 1243; 16/02/1928, p. 1953; 22/03/1931, p. 2327; 25/02/1932, p. 15.

NOTA: Os dados foram extraídos dos Balanços Patrimoniais publicados no Diário Oficial do Estado de São Paulo e agregados em "Ativo Circulante", "Ativo Permanente", "Ativo Total", "Passivo Circulante", "Patrimônio Líquido" e "Passivo Total" pelo autor. A diferença entre Ativo Total e Passivo Total em alguns anos é devido ao arredondamento dos dados. A organização da tabela teve como modelo o trabalho de Marson (2013, p. 17).

Anexo 2: Balanços Patrimoniais da S. A. Fábrica Votorantim, 1932-1939 (em contos de réis correntes)

\begin{tabular}{|c|c|c|c|c|c|c|c|}
\hline Anos & 1932 & 1933 & 1934 & 1935 & 1936 & 1938 & 1939 \\
\hline Ativo Circulante & 32.132 & 30.977 & 30.766 & 26.199 & 23.262 & 48.581 & 52.871 \\
\hline Caixa & 61 & 34 & 139 & 161 & 186 & 259 & 410 \\
\hline Venda de terrenos & 1.949 & & & & & & \\
\hline \multicolumn{8}{|l|}{ Selos de consumo } \\
\hline Devedores diversos & 15.762 & 15.808 & 13.690 & 19.062 & 12.506 & 31.580 & 25.344 \\
\hline Clientes (Letras a receber) & 6.005 & 5.834 & 5.931 & 4.792 & 2.415 & 3.432 & 9.347 \\
\hline Caução dos diretores & 60 & & & & & & \\
\hline Títulos em caução & 2.328 & & 169 & 107 & 112 & 112 & 112 \\
\hline Estoque de mercadorias e matérias-primas & 5.967 & 9.301 & 10.837 & 2.077 & 8.043 & 13.198 & 17.658 \\
\hline Ativo Permanente & 43.839 & 46.070 & 45.961 & 69.568 & 65.161 & 63.168 & 68.913 \\
\hline $\begin{array}{l}\text { Edifício da Fábrica, terrenos e vila operária, fábrica de } \\
\text { cimento Rodovalho, caieiras de Itupararanga, Estrada de } \\
\text { Ferro Elétrica Votorantim, maquinismos, ferramentas, } \\
\text { utensílios, incluindo imóveis, etc. }\end{array}$ & 25.392 & 26.018 & 23.068 & 31.705 & 42.254 & 50.452 & 52.761 \\
\hline $\begin{array}{l}\text { Fábrica de Cimento (custo atual das obra em } \\
\text { andamento e parte dos maquinismos em instalação) }\end{array}$ & & & 5.472 & 17.027 & & & \\
\hline Terrenos diversos e propriedades agrícolas & 3.396 & 3.342 & & & & & \\
\hline \multicolumn{8}{|l|}{ Debêntures em carteira } \\
\hline Ações & 967 & 2.834 & 4.144 & 7.672 & 11.067 & 5.974 & 6.571 \\
\hline Acionistas & 13.500 & 13.500 & 10.000 & 10.000 & 10.000 & & \\
\hline Móveis e utensílios & 29 & 43 & 5 & 823 & 1.449 & 3.022 & 2.746 \\
\hline \multicolumn{8}{|l|}{ Despesas e prêmio de reembolso do empréstimo externo } \\
\hline Contas a liquidar & & & 1.122 & 464 & 217 & 312 & 1.535 \\
\hline Seguros a vencer & 96 & 92 & 98 & 127 & 124 & 132 & 147 \\
\hline Imóveis em construção & 459 & 241 & 2.052 & 1.750 & & 2.369 & 4.479 \\
\hline Plantação de eucaliptos Brooklyn Paulista e outras áreas & & & & & & 853 & 620 \\
\hline Privilégio Municipal (prefeitura de Piedade) & & & & & 50 & 54 & 54 \\
\hline Ativo Total & 75.971 & 77.047 & 83.510* & 95.767 & 88.423 & 111.749 & 121.784 \\
\hline
\end{tabular}




\begin{tabular}{|c|c|c|c|c|c|c|c|}
\hline Passivo Circulante & 48.738 & 46.817 & 55.130 & 60.371 & 52.743 & 61.217 & 65.939 \\
\hline Empréstimo externo & 17.114 & 17.114 & 17.114 & 17.114 & 17.114 & 17.114 & \\
\hline \multicolumn{8}{|l|}{ Emissão de debêntures } \\
\hline Diversos credores & 24.433 & 24.039 & 28.459 & 31.807 & 23.324 & 31.030 & 51.452 \\
\hline Letras a Pagar & 19 & 247 & 3.471 & 7.288 & 5.391 & 4.963 & 5.270 \\
\hline Títulos descontados e caucionados & 2.328 & & & & & & \\
\hline Seção de terrenos & 1.949 & & & & & & \\
\hline \multicolumn{8}{|l|}{ Serviços médicos } \\
\hline Porcentagem dos diretores & 124 & 208 & 327 & 468 & 822 & 968 & 1.166 \\
\hline Salários a pagar & & & 637 & 3.535 & 2.873 & 3.700 & 3.356 \\
\hline Depósito dos diretores & 60 & & & & & & \\
\hline \multicolumn{8}{|l|}{ Debêntures sorteadas e juros não reclamados } \\
\hline \multicolumn{8}{|l|}{ Fundo de depreciação } \\
\hline Impostos & 63 & 126 & 202 & 159 & 279 & 274 & 396 \\
\hline \multicolumn{8}{|l|}{$\begin{array}{l}\text { Diferença de tipo sobre o resgate antecipado de } \\
\text { debêntures }\end{array}$} \\
\hline Dividendos a pagar & 650 & 650 & 3.016 & & & & \\
\hline Reservas Diversas (pagamento de gratificações e férias) & & & & & & 725 & 740 \\
\hline Contas a liquidar & 1.998 & 4.433 & 1.904 & 2.345 & 2.940 & 2.443 & 3.559 \\
\hline Patrimônio Líquido & 27.234 & 28.656 & 29.977 & 32.554 & 36.872 & 49.495 & 55.848 \\
\hline Capital & 20.000 & 20.000 & 20.000 & 20.000 & 20.000 & 20.000 & 20.000 \\
\hline Reservas & 7.103 & 7.670 & 9.977 & 12.554 & 16.872 & 29.495 & 35.848 \\
\hline \multicolumn{8}{|l|}{ Lucros suspensos } \\
\hline Lucros e perdas & 131 & 986 & & & & & \\
\hline Passivo Total & 75.972 & 75.473 & 83510* & 95.270 & 89.615 & 110.712 & 121.787 \\
\hline \multicolumn{8}{|l|}{ Indicadores financeiros } \\
\hline Quociente Cobertura Total & 1,558 & 1,646 & 1,515 & 1,586 & 1,676 & 1,825 & 1,847 \\
\hline Liquidez Corrente & 0,659 & 0,661 & 0,558 & 0,434 & 0,441 & 0,793 & 0,802 \\
\hline Quociente Rentabilidade Patrimônio Líquido & 0,005 & 0,034 & $* *$ & & & & \\
\hline Quociente Rentabilidade do Ativo & 0,002 & 0,013 & $* *$ & & & & \\
\hline \% Capital de Terceiros no Ativo Total & 64,1 & 60,7 & 66 & 63 & 59,6 & 54,8 & 54,1 \\
\hline \% Capital Próprio no Ativo Total & 35,8 & 37,2 & 35,9 & 34 & 41,7 & 44,2 & 45,9 \\
\hline Estrutura Capital: Participação Capital de Terceiros & 1,789 & 1,634 & 1,839 & 1,854 & 1,43 & 1,237 & 1,18 \\
\hline Imobilização do Capital & 1,609 & 1,607 & 1,533 & 2,137 & 1,767 & 1,276 & 1,234 \\
\hline
\end{tabular}

Fonte: SÃO PAULO. Diário Oficial do Estado de São Paulo, 25/02/1933, p. 15; 25/02/1934, p. 32; 27/02/1935, p. 40; 28/02/1936, p. 41; 26/02/1937, p. 56; 20/02/1939, p. 48; 27/02/1940, p. 47.

NOTA: Os dados foram extraídos dos Balanços Patrimoniais publicados no Diário Oficial do Estado de São Paulo e agregados em "Ativo Circulante", "Ativo Permanente", "Ativo Total", "Passivo Circulante", "Patrimônio Líquido" e "Passivo Total" pelo autor. A diferença entre Ativo Total e Passivo Total em alguns anos é devido ao arredondamento dos dados. A organização da tabela teve como modelo o trabalho de Marson (2013, p. 17). 